\title{
Toward Better Resilience during the War Crisis; Case Study of Three Microfinance Institutions in Yemen
}

\author{
Nashwan Sabrah \\ School of Business, Lebanese International University, Sana'a, Yemen \\ E-mail: Nashwans@gmail.com \\ Nabeel T. Alsohybe \\ Faculty of Computer and Information Technology \\ Department of Information Technology, Sana'a University, Sana'a, Yemen \\ E-mail: alsohybe@gmail.com
}

Received: April 19, 2019 Accepted: May 8, 2019 Published: June 6, 2019

doi:10.5296/ber.v9i2.14896 URL: https://doi.org/10.5296/ber.v9i2.14896

\begin{abstract}
As a crisis, man-made or natural disaster, strikes, business management struggles to maintain business, and business sustainability. The management takes different approaches to keep business running during turbulent times such as proactive approach and ad hoc approach. Organizations proactively prepare plans to face predictable changes; however, sometimes the unpredictable changes become very complicated and challenging that would negatively affect these organizations and their business continuity. As a result, it is very crucial for any organization to be well prepared to keep its business running during turbulent times. Currently, there is a major war going on in Yemen since 2015 that negatively affects most of the business sectors in Yemen. Microfinance sector is considered as a very important sector in the country. It is one of the sectors that is affected and hit hard by the ongoing conflict. Thus, the Social Fund for Development, which is the main microfinance industry leader in the country, sought solutions. The researchers conducted a qualitative study on three microfinance pioneers in Yemen and interviewed 11 professionals from all different management levels. The study found that the operations of the studied institutions have been interrupted by four turbulences, and challenged by three market changes which drove these Microfinance Institutions, MFIs, to adapt their strategies and practices.
\end{abstract}

Keywords: Microfinance, War crisis, Agility, Robustness, Resilience, Yemen 


\section{Introduction}

MFIs are known as the financial initiatives of providing small loans and other financial services to poor people, who have no access to formal banking services (Ledgerwood, 1999, p. 2). According to the World Bank, Yemen is one of the poorest countries in the Middle-East and one of the least developing countries in the world with a poverty rate of $54.5 \%$ (worldbank.org, 2012). To help low-income, the Yemeni government in 1997 established and supported several microfinance initiatives (Mansour, 2011, p. 22).

The first microfinance program in Yemen was established in July 1997 with the assistance of the Dutch Government in Hodeida city under Yemen Women's Union umbrella and started operation in 1998. In November 1997, the government through the Social Fund for Development SFD established the Small and Micro Enterprises Development SMED unit to contribute in helping low-income people by providing financial and non-financial services to MFIs that made SFD leads the microfinance industry in Yemen (Mansour, 2011, p. 22).

MFIs are important tools for combating the poverty and improving the well-being of many poor people (Homaid, Zain, Al-matari, Minai, \& Ahmad, 2017). The literature indicates that Yemeni MFIs face challenges responding to their customer's demand (Homaid et al., 2017; Qatinah, 2013). For example, 22\% of MFIs' potential customers (SMEs) did not find appropriate loans to fulfil their needs. In addition, $38 \%$ of borrowers claimed that loans size was not sufficient (Qatinah, 2013, pp. 27-28, 39). Alshebami and Kandare (2014) listed the lack of innovations and customer-driven products as the main MFIs challenges (Alshebami \& Kandare, 2014, p. 410).

What started as some armed conflicts between different parties in 2011, escalated into a major regional war in the country by March 2015. The war crisis in Yemen currently is in its fourth year. It has created one of the worst man-made humanitarian crises in the world. The war has impacted the lives of around 79 per cent of the population. More than 24.1 million people need humanitarian assistance, and over 4 million people are displaced. Since 2015, the economy of Yemen has deflated by nearly 50 percent, and at least 600,000 jobs have been lost. Poverty rate has increased, and more than $80 \%$ of the population are living below the poverty line (U.N. OCHA, 2019, pp. 5-7).

As a result, the Yemeni business environment became unstable and more challenging (Social Fund for Development, 2015, pp. 60-62). Microfinance sector hardly effected and encountered high financial loss (Alshebami \& Rengarajan, 2017, pp. 14-15). Thousands of MFIs' clients changed their base locations while many of them lost their businesses (Yemen Microfinance Network, 2015, p. 5).

Crisis always leads to more market turbulence and to high uncertainty. As a result, it challenges the organization resilience to sustain its original level of performance or achieve new stable one (Wieland \& Marcus, 2013, p. 301). Therefore, the SFD was looking for solutions to enhance MFIs' resilience. This paper is constructed from a case study conducted in 2017 and 2018 with three Yemeni MFIs by the same authors. The first part of the study has been published with a focused scope on the Agility component of the resilience model 
(Alsohybe \& Sabrah, 2019). The purpose of this paper is to bring more insight about the challenges that faced the investigated institutions as well as their actions and reactions toward the current environment turbulence. The paper could help in better understanding of the institutions and supply chain resilience within this unique context of war crisis.

The main sought answers in the paper are for the following questions:

How do the war's consequences challenge the performance, sustainability of investigated institutions?

How did they cope with the environment turbulence?

To answer these questions, this paper presents a set of environment challenges as well as strategies and practices that was implemented by the studied institutions to cope with current crisis.

\section{Theoretical Background}

The literature discussed the resilience concept in two main areas: Organization Resilience and Supply Chains Resilience (Carvalho, Azevedo, \& Cruz-Machado, 2012; Wieland \& Marcus, 2013). Moreover, agility viewed by Wieland and Marcus (2013) as an important component of resilience concept (Wieland \& Marcus, 2013, pp. 310-311). In contrast, some scholars argued that there is only strong correlation between Agility and Resilience concepts (McCann, Selsky, \& Lee, 2009), and the existence of both is important to improve organizations performance (Carvalho et al., 2012). Despite these different understanding of the position of agility, this research work will go with Wieland and Marcus (2013) argument where agility is part of the supply chain resilience that reflected on organization resilience as well.

In turbulent times like in nature crisis time, business environment inherently becomes unstable, and organizations need to cope with such turbulence and the changes they inherent (Wieland \& Marcus, 2013, pp. 310-311). Moreover, business environment turbulence can be demonstrated as demands and customer's requirement changes, market direction changes, and tools and technology changes that requires a new business management way because previous business strategies and practices would no longer be aligned with the actual environment that involved high ambiguity (Akgün \& Keskin, 2014, p. 6921).

Unstable business environment, as result of crisis, brings also another important challenge which is operation disruptions or the unexpected disturbances that affects firm's supply chain operation or firm's performance (Carvalho et al., 2012; Wieland \& Marcus, 2013).

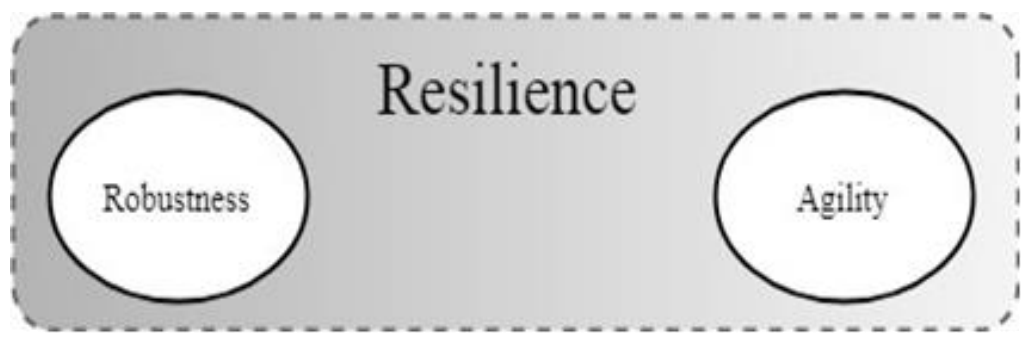

Figure 1. Resilience Components. Source: (Wieland \& Marcus, 2013, p. 304) 
Wieland and Marcus (2013, p. 302) argued that resilience is the ability of a supply chain to cope with changes which formed by two dimensions or strategies: agility as reactive strategy to rapidly respond to change by adapting the initial stable state, and robustness as proactive strategy to resist change without adapting the initial stable configuration where robustness requires predictions of change prior to occurrence. Resilience components are shown Figure 1 .

In addition, from the perspective of the impact of gender diversity on the performance of MFIs in developing countries during turbulent times, Pedrini (2016) argued that MFIs can maintain their performance by focusing on leverage intense innovation, customer intimacy, and team motivation (Pedrini, 2016, pp. 2-3). Also, Fenton et al. (2017) argued that MFIs can reduce their vulnerability during climate crisis by reducing client vulnerability through loan product innovation and being close to their customers (Fenton et al., 2017, p. 21). Moreover, there are strong links between organization resilience capacity, product innovativeness and organization performance (Akgün \& Keskin, 2014, p. 6927).

According to Ismail et al. (2011, p. 17), SMEs can be resilient if they are strategically and operationally agile, in terms of building internal agile capabilities for responding to turbulence that are aligned with its growth strategies.

Moreover, Carvalho et al (2012) argued that obtaining high customer satisfaction by fulfilling the exact customers need as product quality strategy, providing the products required on time with the needed features and quantity as customer service strategy, and introducing new products early as lead time to market strategy are the main supply chain strategic goals to maintain supply chain performance and consequently organization performance in turbulent markets (Carvalho et al., 2012). Furthermore, providing more customer value in terms of conformance to customer specifications and customer satisfaction are mainly required to maintain organization's performance and resilience in the turbulent market (Wieland \& Marcus, 2013, p. 307).

However, MFIs products and strategies, typically, are driven by the supply condition, donors' requirements (Brand, 1998a, pp. 3-4), or based on their internal conditions, strengths and weaknesses (Kapoor \& Sinha, 2013, p. 101) instead of being customers driven (Brand, 1998, pp. 3-4; Kapoor \& Sinha, 2013).

\section{Research Methods}

To investigate a phenomenon in a real-life where behaviour controlling is not required, the qualitative case study approach is considered as a suitable one according to (Creswell, 2007, pp. 39-40; Yin, 2014, p. 12). Moreover, the qualitative study research is used when the problem needs to be explored through studying individuals to obtain their understanding regarding the phenomena or the issue where the phenomena cannot be separated from its context (Creswell, 2007, pp. 39-40; Yin, 2014, p. 12).

Due to the contextual nature of the issue and for bringing more insight into the problem in a real-life, the researchers selected qualitative case study method. In addition, according to Yin (2014), doing two cases produce a better result than using a single case design which allows 
replication and comparing the outcomes of both cases to produce more robust conclusions (p.63-64). Also, multiple case study is used to show similarity (literal replication) or difference in the predicted results -theoretical replication (Cooper \& Schindler, 2014, pp. 165-166; Yin, 2014). Thus, this research uses multiple case designs as a literal replication for the reason of showing similarity that would help in making a solid result.

According to Creswell (2007, pp. 74-75), the procedure of conducting a case study starts by defining the rationale for selecting the study approach and sampling strategy. The second step of the procedure is the data collection that includes multiple sources of data. The third step is the analysis strategy, and the final step is the conclusion and research report (Creswell 2007, pp. 74-75). The researchers used the literature review to gain more information about the problem and initiate the conceptual framework. Based on the study framework, the interview guide has been developed and tested through a pilot case study. The data collection procedure and the interview guide have been refined by the researchers based on the pilot study results. Collecting evidence from the real-life environment was based on semi-structured interviews, and from reviewing the institution's relevant documents.

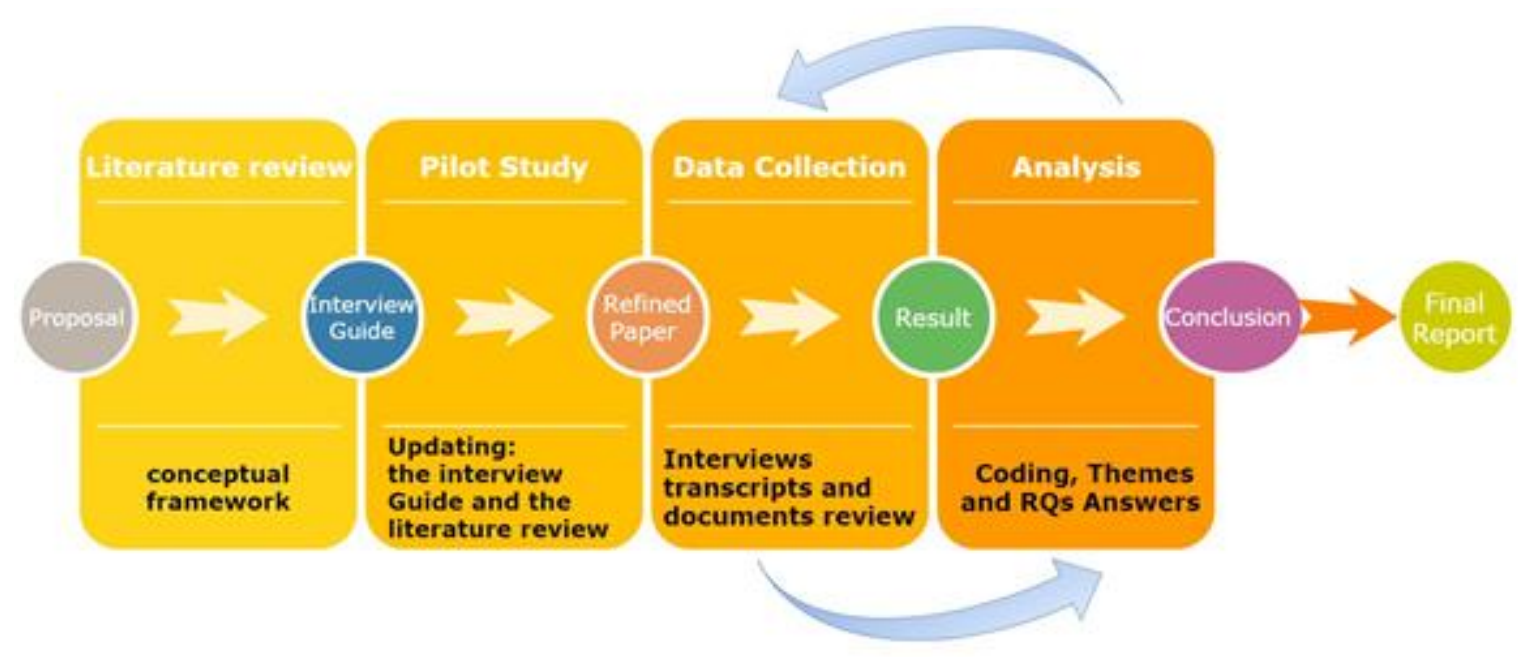

Figure .2 process of this study; illustrated by the authors The general

Finally, this study used contents and thematic analysis to construct the result and draw the conclusion and recommendations. Moreover, the researchers conducted the data collection and analysis stages in iterations; for example, the researchers started with interviewing the available individuals then conducting quick analysis to make sure that themes are clear. Whenever themes were not clear, the researchers looked for additional individual in iteration until themes identified clearly. Furthermore, the same data collection and analysis process have been applied by the researchers in all cases. Figure 2 illustrates the general process of this study.

In practice, many cases are selected based on availability (Runeson \& Höst, 2009, p. 140) or accessibility (Creswell, 2007, p. 75). The case studies of this research have been selected based on the following criteria: 1) most recently has been involved in developing new financial products, 2) willing to provide the required access to all relevant data and individuals, and 3) showing interest on the research subject. Moreover, according to Yin 


\section{Macrothink}

Business and Economic Research

ISSN 2162-4860

2019, Vol. 9, No. 2

(2014), probability sampling method is not an appropriate way of selecting case study (p. 59).

According to (D. R. Cooper \& Schindler, 2014, p. 152), Qualitative research involves non-probability sampling such as:

- Planned sampling: choosing participants based on predefined criteria such as their experiences.

- Incremental sampling (Snowball): asking first participants to refer to others who have for example similar experiences or different from their own.

- Availability based sampling: selecting any available individuals as participants (D. R. Cooper \& Schindler, 2014, p. 152).

Therefore, selecting the interviewee's sample was based on the Snowball sampling where the researchers started with the available person in a decision-making position then asking him or her to suggest the next participants and so on until the research questions being answered and themes were identified.

Thus, the list of interviewees was defined during the research progress; which is the typical way in qualitative research (D. R. Cooper \& Schindler, 2014, p. 152). In total, 11 individuals were interviewed as presented in Figure 3.

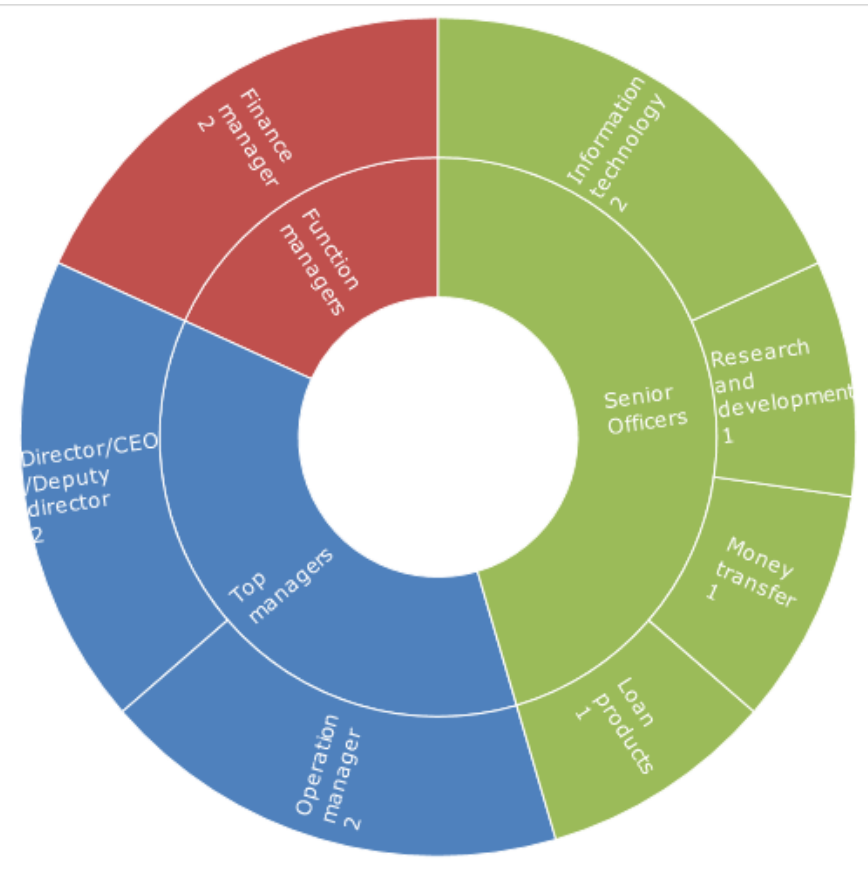

Figure 3. The interviewees number based on job positions

Furthermore, the following contents analysis steps have been performed by the researchers:

1. The interviews have been digitally recorded using Atlas-TI mobile application.

2. A transcript of all interviews and workshop discussions has been made

3. Interesting quotes have been identified using Atlas-TI application, and after reading 
the transcripts carefully, quotes are coded and mapped to the study framework.

4. Important quotations have been translated from Arabic to English by an authorized translator.

5. Codes have been categorized and based on that, themes of each case are identified.

6. Conducting cross-cases comparative analysis of the constructed results.

7. Identifying the overall themes.

Since this study is based on the qualitative methodology, triangulation was used for the collection of the primary data. The term Triangulation refers to the combining of several qualitative methods or combining qualitative with quantitative methods to overcome the perceived weaknesses of a single-shot approach (D. R. Cooper \& Schindler, 2014, p. 166).

Therefore, the data collection is triangulated by using semi-structured interviews, institutions' documents review, and consulting the literature.

\subsection{Case Overview}

Institutions profile information shown in Table 1; all institutions are focusing on providing ;2 saving and -Islamic loans, and only case A has additional types of products which are micro .money transfer

Table 1. Institutions' profile overview

\begin{tabular}{|l|l|l|l|}
\hline Context elements & A: The Bank & B: The Program & C: The Foundation \\
\hline Establishment year & 2009 & 2001 & 2000 \\
\hline Products & $\begin{array}{l}\text { Islamic-loans, Micro-saving, } \\
\text { and money transfer }\end{array}$ & Islamic loans only & Islamic loans only \\
\hline Employees No. & 177 & 80 & 104 \\
\hline Branches & 18 & 5 & 10 \\
\hline Portfolio Sep-2017 & 2,318 Million YR & 363 Million YR & 434 Million YR* \\
\hline OSS* Sep-2017 & $185 \%$ & $41 \%$ & $134 \%$ \\
\hline FSS* Sep-2017 & $78 \%$ & $30 \%$ & $109 \%$ \\
\hline
\end{tabular}

* OSS; operational self- sufficiency; FSS: financial self-sufficiency; YR: Yemeni Rial

\section{Results}

All cases faced external pressure from demand changes and the rising competition in some market areas and products. The market uncertainty and the operation disruptions also have been recognized by Case $\mathrm{A}$ and Case $\mathrm{C}$ as an important pressure that affects the institution's performance. The possible reason that Case B didn't face high pressure from the operation disruptions because all branches of Case B distributed in one province that stayed out of any land clashes. Therefore, all cases adopted new strategies and practices to cope with the external forces. The below list contains the main categories of the external pressure as well as the new resilience strategies which will be discussed in the next section. 
The result categorized into two main items and several sub-items as the following list:

1. Main external environment's pressure

1.1. Market changes: changes in demand, changes in the competitive landscape, and market uncertainty increases

1.2. Operation disruptions: closing some branches, disruption of loans disbursement, and disruptions of installment collection efforts.

2. Resilience strategies and practices:

2.1. Market responsiveness strategy. Responding to the market changes through product innovations

2.2. Contingency plan: responding to any disruptions and expected risks

2.3. Recovery plan: finding external support for institution recovery and its customers recovery.

\section{Analysis and Discussion}

Current war crisis has caused several market changes that threaten the business continuity of the investigated institutions. This paper is focusing on exploring the external environment forces that affect the operation of the studied cases during the current war crisis and investigating the strategies of these cases to deal with these pressures to determine any alignments between the external pressures and institution strategies.

In all cases, the external pressure drives the institutions to change their strategies to be more responsive to the market needs. The study shows that more than 10 different types of external turbulence exist. These turbulence lead to several challenges related to the market changes and operation disruptions. As mentioned before, this paper specifically focuses on the component of resilience model. Within this framing, the main external pressure/challenges and resilience strategies were analysed and discussed.

\subsection{External Environment's Challenges}

Since the beginning of the war in March 2015, the institutions have been affected by several turbulence factors that hinder their performance (Alshebami \& Rengarajan, 2017; Yemen Microfinance Network, 2015).

Therefore, the first question was, "What are the external factors that have affected your institution during the current war crisis?". According to respondents, the environment turbulence such as, the business projects destruction of many clients, salaries discontinuity of the government's employees, and the inflation, which categorized under declines of people's income, as well as the lack of government services including the security services, and clients' displacement due to clashes and bombardment, have led to several disruptions: 1) loans disbursement "Many of the financing products have stopped, for example the care product, due to the discontinuation of social welfare programs, the product of the group, due to the wars and displacement, the product of partnership, due to the suspension of salaries and 
their instability, interviewee 1-p5 said", 2) instalment collection "We hardly recovered of the first blow regarding the suspension of some of our branches and the effect on customers and they stopped paying for up to four or five months, where we suffered a lot in the collection of our funds, especially in 2015. Interviewee 3-p1 said", and 3) overall operation in some branches. The summary of the environment turbulence and its effects on the institution's operation shown in Table 2.

Table 2. Summary of the environment turbulence and its impact

\begin{tabular}{|c|l|l|l|}
\hline$\#$ & Turbulence & Found in & Impact \\
\hline 1 & Income declines & Case A, B, C & $\begin{array}{l}\text { Disruption of loans disbursement, } \\
\text { Disruptions of installments collection } \\
\text { efforts }\end{array}$ \\
\hline 2 & Poor or lack of government services & Case A, B, C & Case A, C \\
\hline 4 & Land clashes and security absenteeism** & Case A, C & $\begin{array}{l}\text { Closing some branches temporary or } \\
\text { completely, which disrupt loans } \\
\text { disbursement and collecting loans } \\
\text { installments }\end{array}$ \\
\hline
\end{tabular}

*,**: These factors were not shown in Case B that can be justified as its all branches are placed in save areas

The interviewees were asked to provide their opinion on describing the current market attributes compared to the attributes before the war. As a result, according to their answers, the Market landscape has been changed: "The market is competitive and has changed dramatically. Interviewee 2-p3“. The demand of some Loans products is decreased, and many credit products become obsolete. For instance, when many clients failed to fulfil the loans' conditions, and the diminishing of the customers need for loans to buy electronic devices or consumer goods: "In the past, we used to focus on consumer loans, which had a good revenue and quality for the portfolio in terms of loans number. But now we are going to finance income-generating activities. Interviewee 2-p3“.

On the other hand, changes in market demand bring new opportunities too. For instance, interviewees identified new high demand for loans of solar energy appliances due to the absence of the public electricity services. In case A interviewees identified a high increase in the need for social money transfer due to the increasing number of people in need for assistance: "There have been opportunities or positive aspects in the fact that the international organizations working in Yemen are providing aid to those affected by the current crisis, so we have an opportunity to work on the product of social transfers. Interviewee 1-p8". Moreover, several interviewees think that the market demand and customers need to become vary from geographic area to another.

Additionally, this study found a rise in the level of competition between the MFIs in the contrary with what was expected since the literature indicated that the level of competition in most of the microfinance markets is low (Brand, 1998b; Kapoor \& Sinha, 2013). The reason for this change in the competition level is due to the crisis attributes as what the interviewees 


\section{Macrothink}

Business and Economic Research ISSN 2162-4860 2019, Vol. 9, No. 2

pointed to. For example, high competition started around few secured and low-risks areas: "In the Hodeida area, the competition has become very strong between us and "other competitor" and in Ibb area as well, as safe areas. Interviewee 3-p1". And, also due to the business damage of many good customers, the institutions compete for retaining their good customers or acquiring new ones. Moreover, the good financial return from the social money transfer has encouraged the commercial banks to enter the market and compete with the MFIs.

In answering the question "How do you get information about variables in the market?", respondents mentioned several challenges in getting the required information on time due to the complexity of the current security situation: "It is very, very difficult now to conduct a survey, even entering the field to a small area to collect data requires approvals and significant costs. There are places of conflict that we cannot enter forever.", and due to the lack of the official services: "The access to information from the official authorities has become non-existent. Interviewee 1-p3".

The institutions suffer from high market uncertainty: "long-term prediction of market variables is difficult currently and limited to three or six months as a maximum period due to the unstable state and frequent changes. Interviewee 2-p2".

Thus, themes of the market changes have been categorized to 1) changes in demand, 2) higher competition level, 3) and market uncertainty. Figure 4 shows the main categories, and themes of market changes attributes for each case.

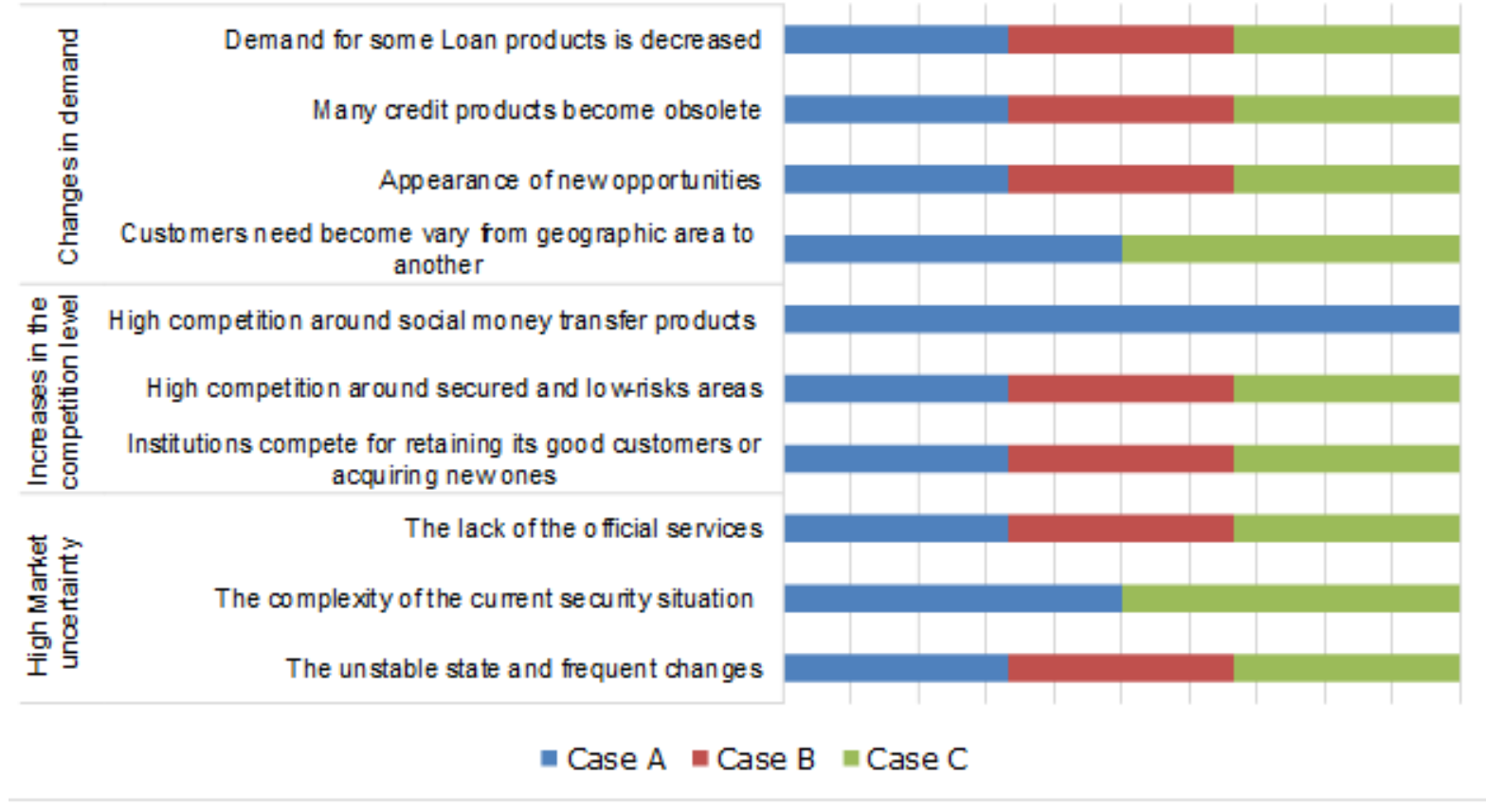

Figure 4. Themes of market changes and its attributes

\subsection{Resilience Strategies and Practices}

Noticeably, business environment turbulence that causes changes in demands and market 


\section{Macrothink}

Business and Economic Research

ISSN 2162-4860

2019, Vol. 9, No. 2

direction requires a new business management approach because previous business strategies and practices would no longer be aligned with the actual environment which involves high ambiguity due to a lack of enough market information (Akgün \& Keskin, 2014, p. 6921).

The second main question was "In your opinion what has helped your institution to survive? In terms of strategies and practices". According to participants, their institutions resisted current turmoil environment by adopting new strategies. For instance, at the beginning of the war, Case $\mathrm{A}$ and $\mathrm{C}$ concentrated on collecting instalments of loans and adopting deflation strategy: "At the beginning of the events, we adopted a deflationary strategy from 2015 to 2016. interviewee 3-p2". Later-on, these two institutions changed their strategies to a responsiveness strategy: "If there is no adjustment and flexibility, I expect, according to our situation a year ago, that the situation now will be much worse. And I think responding easily and flexibly achieved steadfastness for us. Interviewee 2-p2", by targeting new areas and launching new products.

Moreover, case A adapted its strategies early by concentrating on innovating new products through modifying existing ones and adjusting products features frequently. The practices of modifying and adjusting products features frequently have been used in all cases to respond to market changes which allow the institutions to generate more revenue: " $80 \%$ of our revenues in this year came from new products. interviewee 1-p3"

According to previous studies, leveraging intense product innovation contributes in maintaining MFIs performance and resilience during turbulent time (Pedrini, 2016, pp. 2-3) (Fenton, Tallontire, \& Paavola, 2017, p. 21). Thus, the finding of this study is aligned with the literature regarding the important of products innovation in helping institutions to cope with unstable environment.

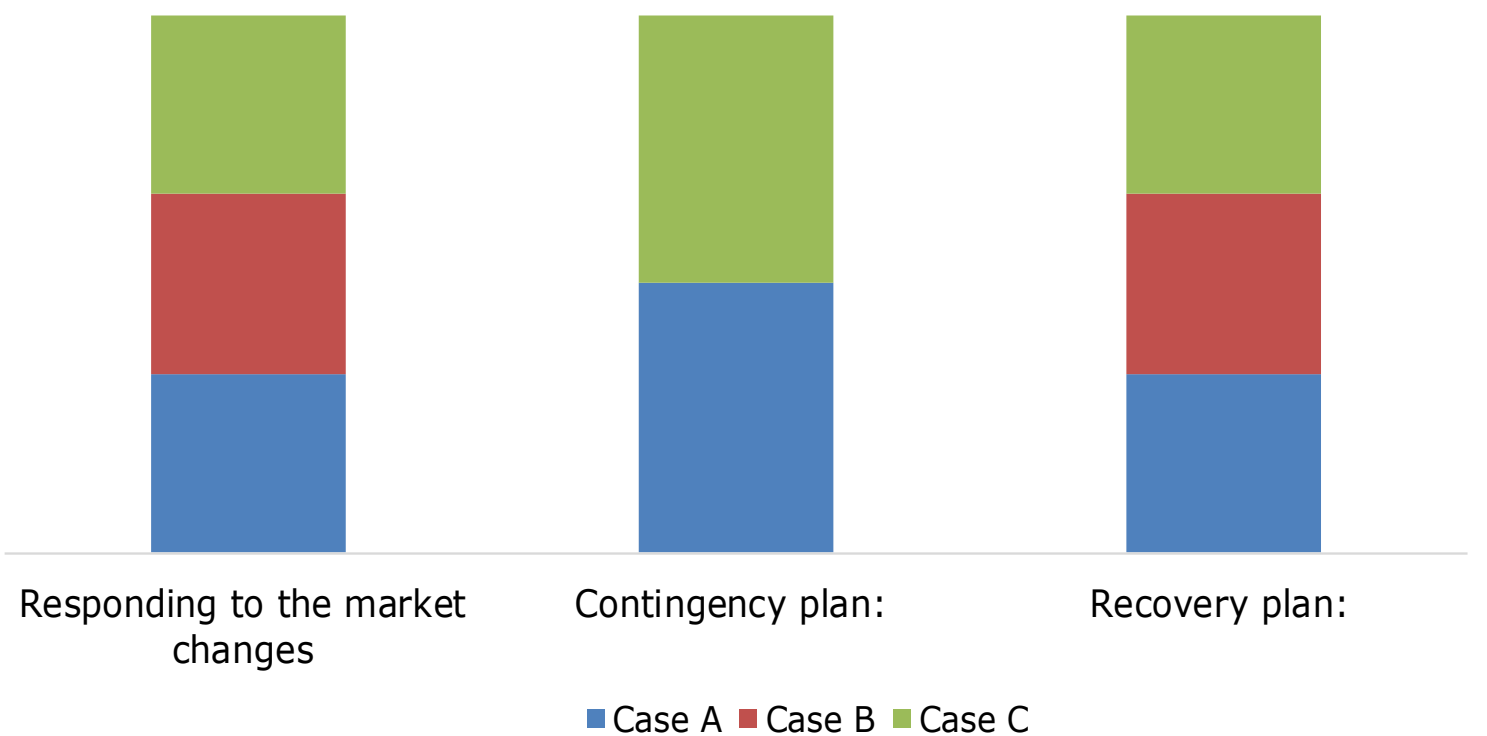

Figure 5. Strategies that employed by investigated institutions

Furthermore, two cases were implemented a contingency plan, see figure 5. They have been 
frequently reviewed based on their prediction and expectations of the conflict direction: "we are working on a ccontingency plan, not the actual business plan. And this plan is reviewed monthly or weekly in some places or every three months in stable places. Interviewee 1-p3“. This strategy allowed the institutions to quickly respond to the disruptions based on pre-planned actions where the delegated authority to branches managers and areas managers allowed them to act immediately based on their evaluation of the situation.

Moreover, when the crisis consequences exceed the institution capacity to overcome, they prepared a recovery plan based on their damages and predicted consequences. And based on that plan, the studied cases called the government and other non-government supporters to help on funding their recovery plans. Also, in-order to retain good customers and maintain the institution's reputation, the investigated institutions identified their customer vulnerability in terms of their need to recover their business again and include them in the recovery plan. Table 3 summarizes the finding results regarding strategies and practices that employed by investigated institutions to cope with environment turbulence.

According to one of the managers, the external support is the main factor that allow all MFIs to continue. "Had not the Social Fund provided grants for continuity, the institution would have ceased, not only us, but all microfinance institutions. The Social Fund has also provided grants to help those affected from our clients to recover their activity. Interviewee 3-p1".

Table 3. Summary of the adapted strategies and practices

\begin{tabular}{|l|l|}
\hline Resilience's Strategies & Practices \\
\hline Responding to the market needs & $\begin{array}{l}\text { Innovating new products by modifying existing ones and } \\
\text { frequently adjusting their products, mainly to respond to } \\
\text { the market changes }\end{array}$ \\
\hline Contingency plan & $\begin{array}{l}\text { Continuous planning and delegation of authority to } \\
\text { responding to any disruptions and expected risks }\end{array}$ \\
\hline Recovery plan & $\begin{array}{l}\text { Finding external support for institution recovery and } \\
\text { customer recovery through its relationships with } \\
\text { government and international agencies }\end{array}$ \\
\hline
\end{tabular}

Regarding the resilience model of Wieland and Marcus (2013), all investigated cases leverage the Agility dimension by adapting a responsiveness strategy for the market's need through products innovation. Visibility of change occurrence has mainly obtained through the daily face-to-face communications between loan officers and customers and by maintaining a good relationship with their clients, external donors, and supporters. Apply the required change rapidly has been obtaining through the product development teams by starting new ad-hoc practices and adapt current process for obtaining better flexibility to reasons, which was noticed in case A and B. Moreover, in case A and C, the contingency plan has been managed with certain degree of flexibility.

In addition, regarding the second component of resilience model of Wieland and Marcus (2013), which is the robustness as proactive strategy, Case A and C have developed a contingency plan based on their anticipation of the future risks. Similarly, all cases prepared 
recovery plans and were looking for external fund for its own recovery and their affected customers too.

According to the case study of First-Microfinance, Syria FMFI-S (Merchant \& Pascutto, 2016), during Syria war crisis, the institution achieved $61 \%$ increases in the number of depositors and reached 23,273 borrowers with USD \$10.49 million outstanding portfolio in 2016 through adopting a client-focused responsiveness strategy and continuously update its policies and products according to different local contexts. The FMFI-S case study shows several lessons learned similar to this research's findings. For instance, the importance of products innovation, adjusting products features frequently to meet the exact market needs, delegate enough authority to branches managers and areas managers to respond quickly to the environment changes, continuous planning and review of environment condition, and finding external support for institution recovery and customer recovery (Merchant \& Pascutto, 2016).

\section{Conclusion}

This paper presents a series of challenges related to the current war consequences in three MFIs in Republic of Yemen and provides an overview of their employed actions regarding coping with current environment. The operation of the investigated institutions disrupted by the decline of the people income and the damage and displacement occurred in their branches and customer's areas. In addition, these institutions' performance challenged by several market changes such as demand, competition and uncertainty. Therefore, they start to adapt several new strategies and practices to survive and achieve better resilience and performance levels. These strategies and practices include responding to the market and customers' needs through product innovations and maintaining their service continuity through contingency and recovery plans. Figure 6 summarized the finding result in link with the resilience model of Wieland and Marcus (2013). 


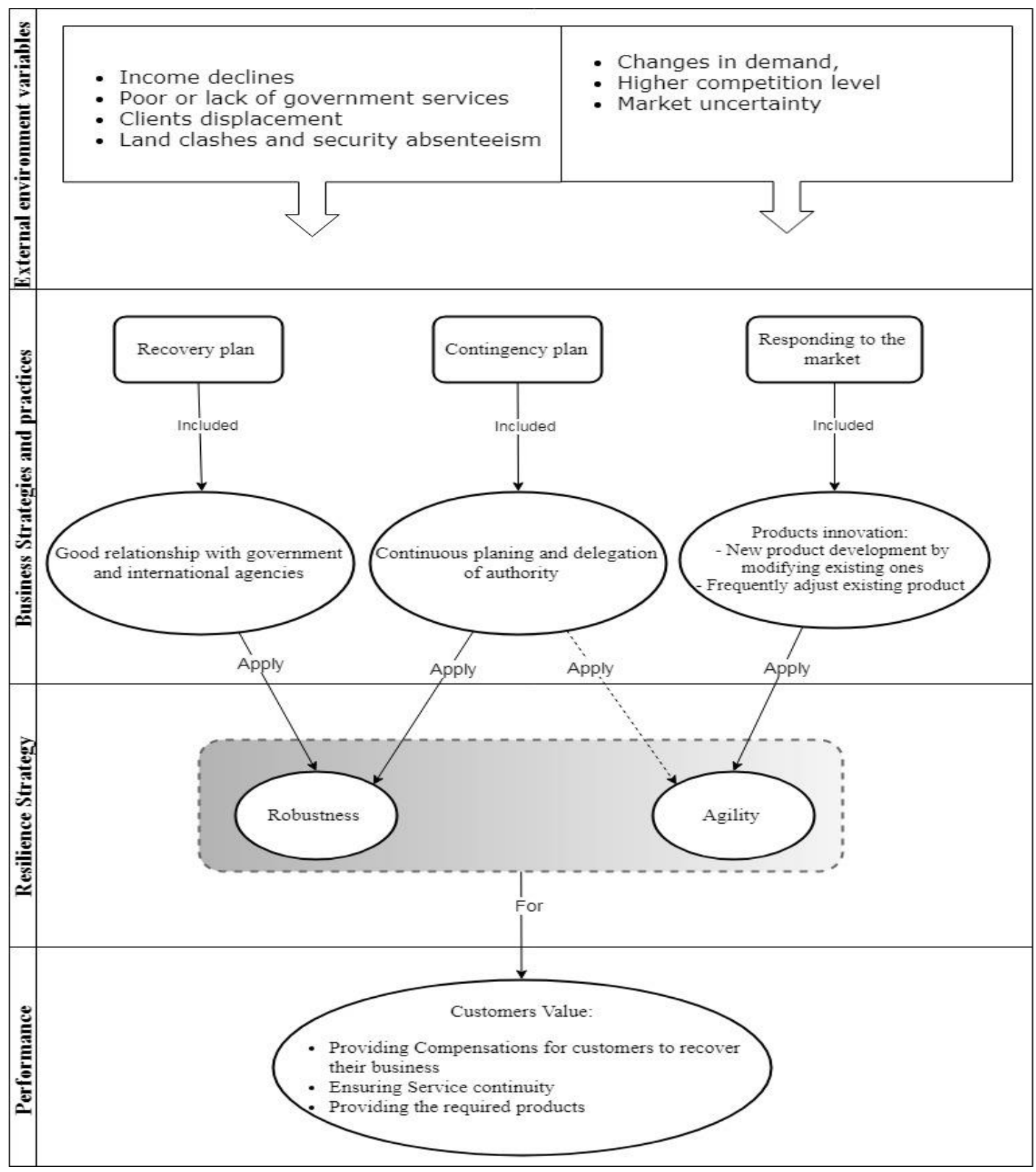

Figure 6. Study's result summary

This study recommends the institutions to continue adjusting their polices, strategies and practices based on their lessons learned and to continue seeking more help from professional organizations, researchers, and donors to enhance their resilience capabilities.

The authors in a published paper provided more insight about how these institutions can leverage better agility in responding to their customers need and market changes as a part of enhancing their resilience capabilities (Alsohybe \& Sabrah, 2019).

\section{References}

Akgün, A. E., \& Keskin, H. (2014). Organisational resilience capacity and firm product innovativeness and performance. International Journal of Production Research, 52(23), 6918-6937. https://doi.org/10.1080/00207543.2014.910624 
Alshebami, A. S., \& Kandare, M. (2014). Microfinance in Yemen "Challenges and Opportunities". IJMSS, 2(12), 400-413.

Alshebami, A. S., \& Rengarajan, V. (2017). Microfinance Institutions in Yemen "Hurdles and Remedies.” International Journal of Social Work, 4(1), 10-21.

https://doi.org/10.5296/ijsw.v4i1.10695

Alsohybe, N. T., \& Sabrah, N. (2019). Agile project management in non-software sectors during turbulent times. International Journal of Software Engineering \& Applications IJSEA, 10(1), 51-68. https://doi.org/10.5121/ijsea.2019.10104

Brand, M. (1998a). New Product Development for Microfinance: Design, Testing, and Launch Technical Note Number 2.

Brand, M. (1998b). New Product Development for Microfinance: Evaluation and Preparation Technical Note Number 1. ACCION International.

Carvalho, H., Azevedo, S., \& Cruz-Machado, V. (2012). Agile and resilient approaches to supply chain management: influence on performance and competitiveness. Logistics Research, 4, 49-62. https://doi.org/10.1007/s12159-012-0064-2

Cooper, D. R., \& Schindler, P. S. (2014). Business research methods (Twelfth Edition). McGraw-Hill/Irwin.

Creswell, J. W. (2007). Qualitative inquiry\& research design - Choosing Among Five Approaches (Second Edition). Thousand Oaks: SAGE Publications.

Fenton, A., Tallontire, A., \& Paavola, J. (2017). Vulnerability of microfinance institutions to climate risk in the Satkhira District, Southwest Bangladesh. Centre for Climate Change Economics and Policy Working Paper No. 302. Leeds.

Homaid, A. A., Zain, A. Y., Al-matari, Y. A., Minai, M. S., \& Ahmad, F. Bin. (2017). The Role of customer-focused strategies to improve Islamic microfinance institutions performance: Empirical evidence and lessons from Yemen. International Review of Management and Marketing, 7(1), 291-299.

Ismail, H. S., Poolton, J., \& Sharifi, H. (2011). The role of agile strategic capabilities in achieving resilience in manufacturing-based small companies. International Journal of Production Research, 1-19. https://doi.org/10.1080/00207543.2011.563833

Kapoor, S., \& Sinha, G. (2013). Factors influencing new product development in microfinance institutions: A perspective from north Indian microfinance institutions. Journal of Innovation Economics \& Management, 11(1), 83. https://doi.org/10.3917/jie.011.0083

Ledgerwood, J. (1999). Microfinance Handbook: An Institutional and Financial Perspective. Washington,D. C.: The World Bank.

Mansour, A. (2011). Yemen Small and Micro Enterprises Development in Yemen and Future Prospects. Social Fund for Development, Annual Report. Sana'a. 
McCann, J., Selsky, J., \& Lee, J. (2009). Building Agility, Resilience and Performance in Turbulent Environments. People and Strategy, 32(3).

Merchant, S., \& Pascutto, B. (2016). Case study in disaster risk reduction, first microfinance institution Syria: building resilience through a client-centric model. Retrieved from http://www.findevgateway.org/sites/default/files/publication_files/drr_case_studyakam_8.pdf

Pedrini, M. (2016). Exploring the effect of gender diversity in MFIs during turbulent periods. The International Journal of Human Resource Management, 5192(November), 1-27. https://doi.org/10.1080/09585192.2016.1246460

Qatinah, A. A. (2013). Factors Affecting Microfinance Demand and Supply Gaps in Yemen. (Master Thesis, Phillipps University of Marburg).

Runeson, P., \& Höst, M. (2009). Guidelines for conducting and reporting case study research in software engineering, 131-164. https://doi.org/10.1007/s10664-008-9102-8

Social Fund for Development. (2015). SFD annual report 2015. [Online] Available: http://www.sfd-yemen.org/content/17/9

U.N. OCHA. (2019). Yemen: Humanitarian Response Plan - January-December 2019. [Online] Available:

https://reliefweb.int/sites/reliefweb.int/files/resources/2019_Yemen_HRP_V21.pdf

Wieland, A., \& Marcus, C. (2013). The influence of relational competencies on supply chain resilience: a relational view. International Journal of Physical Distribution \& Logistics Management, 43(4), 300-320. https://doi.org/10.1108/IJPDLM-08-2012-0243

worldbank.org. (2012). Yemen-talking-points. Retrieved March 10, 2017, from http://www.worldbank.org/en/news/feature/2012/09/26/yemen-talking-points

Yemen Microfinance Network. (2015). Microfinance in Yemen, Hopes vs. Reality: A first insight into the impact of war on the industry. Sana'a.

Yin, R. K. (2014). Case study research. Design and Methods (5th edition). Thousand Oaks: SAGE Publications.

\section{Glossary}

Organization's resilience: is the ability of an organization's supply chain to cope with environmental changes through agility and robustness strategies (Wieland \& Marcus, 2013, pp. 301, 310-311)

Organization's performance: refers to the supply chain's customer value that comes from the organization's conformance to customer specifications and satisfaction as the main performance indicator resulting from resilience (Wieland \& Marcus, 2013, p. 307).

\section{Abbreviations}

CGAP: Consultative Group to Assist the Poor 


\section{1) Macrothink}

FSS: Financial self-sufficiency

MFIs: Microfinance Institutions

OSS: Operational self- sufficiency

SFD: Social Fund for Development

SME: Small and Medium-Sized Enterprises

SMED: Small \& Micro Enterprise Development Unit

YMN: Yemen Microfinance Network

\section{Copyright Disclaimer}

Copyright for this article is retained by the author(s), with first publication rights granted to the journal.

This is an open-access article distributed under the terms and conditions of the Creative Commons Attribution license (http://creativecommons.org/licenses/by/3.0/). 